\title{
Changes in Carbon Partitioning and Accumulation Patterns during Drought and Recovery for Colonial Bentgrass, Creeping Bentgrass, and Velvet Bentgrass
}

\author{
Michelle DaCosta and Bingru Huang ${ }^{1}$ \\ Department of Plant Biology and Pathology, Rutgers University, New Brunswick, NJ 08901
}

AdDitional INDEX words. Agrostis, total nonstructural carbohydrates, turfgrass

\begin{abstract}
Efficient carbon distribution and utilization may enhance drought survival and recovery ability for perennial grasses. The objectives of this study were to examine changes in carbon partitioning and carbohydrate accumulation patterns in shoots and roots of colonial bentgrass (Agrostis capillaris L.), creeping bentgrass (A. stolonifera L.), and velvet bentgrass (A. canina $\mathrm{L}$.) in response to drought and re-watering following drought, and to determine whether species variation in drought tolerance and recuperative potential is related to differences in the patterns of carbon partitioning and accumulation. The experiment consisted of three treatments: 1) well-watered control; 2) drought, irrigation completely withheld for 18 days; and 3) drought recovery, a group of drought-stressed plants were re-watered at the end of the drought treatment (18 days). Drought tolerance and recuperative ability of three species was evaluated by measuring turf quality and leaf relative water content. These parameters indicated that velvet bentgrass was most drought tolerant while colonial bentgrass had highest recuperative ability among the three species. Plants were labeled with ${ }^{14} \mathrm{CO}_{2}$ to determine carbon partitioning to shoots and roots. Carbohydrate accumulation was assessed by total nonstructural carbohydrate (TNC) content. The proportion of newly photosynthesized ${ }^{14} \mathrm{C}$ partitioned to roots increased at 12 days of drought compared to the pre-stress level, to a greater extent for velvet bentgrass (45\%) than for colonial bentgrass $(35 \%)$ and creeping bentgrass $(30 \%)$. In general, the proportion of ${ }^{14} \mathrm{C}$ was highest in roots, intermediate in stems, and lowest in leaves at 12 days of drought treatment for all three bentgrass species. As drought duration and severity increased (18 days), ${ }^{14} \mathrm{C}$ partitioning increased more in leaves and stems relative to that in roots for all three species. Stem TNC content was significantly greater for drought-stressed plants of colonial bentgrass and velvet bentgrass compared to their respective well-watered control plants, whereas no differences in stem TNC content were observed between drought-stressed and well-watered creeping bentgrass. Our results suggest that increased carbon partitioning to roots during initial drought stress represented an adaptive response of bentgrass species to short-term drought stress, and increased carbon partitioning and carbohydrate accumulation in stems during prolonged period of drought stress could be beneficial for rapid recovery of turf growth and water status upon re-watering.
\end{abstract}

Carbohydrates provide energy and carbon skeletons for various metabolic processes and ultimately affect plant growth and survival. Carbon metabolism, including photosynthesis, respiration, allocation to different metabolic pools, and partitioning among various organs (e.g., leaves, stems, and roots), is affected by environmental factors, such as water availability (Chaves, 1991). Increased carbon investment in roots in response to soil water deficit has been observed in many species, which is reflected by increased carbon partitioning to roots and increased root-to-shoot biomass ratio (Bradford and Hsiao, 1982; Hamblin et al., 1990; Mooney and Winner, 1991). The shift in carbon partitioning patterns in favor of roots promotes deep rooting and utilization of water deeper in the soil profile, and thus contributes to drought resistance in various plant species, including perennial (Assuero et al., 2002; Volaire, 1995) and annual grasses (Kalapos et al., 1996; Nicolas et al., 1985; Simane et al., 1993). This in turn may allow the plant to avoid or delay tissue dehydration and maintain favorable shoot water relations for maintenance of physiological and metabolic functions. Huang and Gao (2000) reported

Received for publication 18 Oct. 2005. Accepted for publication 8 Mar. 2006. The authors wish to thank Dr. Shimon Rachmilevitch and Dr. Stacy Bonos for critical review and suggestions on the manuscript. Thanks also go to Dr. Shimon Rachmilevitch for assisting in the radioactive labeling work. Partial funding for this study was provided by the Rutgers University Center for Turfgrass Science. 1To whom reprint requests should be addressed. Email address: huang@aesop. rutgers.edu greater partitioning of newly photosynthesized carbon to roots for drought-tolerant cultivars of tall fescue (Festuca arundinacea Shreb.) under soil drying. When grown in monoculture under water deficit, increased root-to-shoot ratios were associated with the ability of Mediterranean-type tall fescue plants to maintain higher water status compared to temperate tall fescue cultivars (Assuero et al., 2002).

In addition to modifications in carbon partitioning patterns, the availability and utilization of carbohydrates also change during stress and recovery from stress. The quantification of TNC within plant tissue has been utilized as an indirect measure for turfgrass physiological status in response to environmental and cultural factors (Hull, 1992; Narra et al., 2004; Sheffer et al., 1979; Volenec, 1986). TNC may serve as energy currency within plants to be utilized towards growth, maintenance, and recovery from stress (Hull, 1992). Huang and Gao (2000) and Huang and $\mathrm{Fu}$ (2000) reported that TNC levels were either unaffected or increased in tall fescue and kentucky bluegrass (Poa pratensis L.) in response to soil drying. Increased carbohydrate accumulation may be related to inhibition of plant growth before photosynthesis is significantly affected (Chaves, 1991; Hsiao, 1973). Furthermore, storage carbohydrates may also be hydrolyzed and contribute to higher concentrations of simple sugars in drought-stressed grasses (Spollen and Nelson, 1994; Suzuki, 1993). Increases in soluble sugars, a component of TNC, in combination with other solutes may contribute to osmotic adjustment by lowering leaf water 
potential at which stomatal closure occurs and sustain turgor in growing regions of leaves and roots (Chaves, 1991; Godde, 1999; Richardson et al., 1992). Additionally, these reserves may be utilized as the primary source of carbohydrates for continued biomass production throughout drought or during recovery from drought (Chaves, 1991).

In perennial grass species, survival or persistence under prolonged drought may be important for recovery from the stress when water becomes available. Perennial species may allocate more carbohydrates to storage organs, such as stem and leaf bases, as a survival mechanism rather than for continued growth under drought stress (Volaire et al., 1998). In Themeda triandra Forssk., a $\mathrm{C}_{4}$ perennial forage grass, severe drought stress induced carbohydrate partitioning primarily to stem bases, which served as important reserve pools for re-growth following stress (Oosthuizen and Snyman, 2001). Drought-tolerant populations of orchard grass (Dactylis glomerata L.) also accumulated significant amounts of carbohydrates in leaf bases, while more drought-susceptible populations continuously utilized carbohydrate reserves for growth during drought stress (Volaire, 1995). In white clover (Trifolium repens L.), a majority of carbohydrates were stored in stolons during water deficit, which subsequently aided plant recovery from drought stress (Turner, 1990).

Creeping bentgrass, colonial bentgrass, and velvet bentgrass are perennial grass species commonly utilized on golf courses in cool, humid climatic regions. The ability of plant adaptation to drought stress has been reported to vary among the three bentgrass species. Compared among the three species, velvet bentgrass demonstrated better drought tolerance than colonial bentgrass or creeping bentgrass, as exhibited by higher turfgrass quality, higher canopy photosynthetic rates, and higher soil water content under deficit irrigation regimes (DaCosta and Huang, 2006). However, the relative recuperative potential of the three species are not well documented. Persistence during drought stress and rapid recovery from drought injury are important traits required for turfgrasses grown in areas with limited rainfall or irrigation. Changes in carbohydrate accumulation and partitioning patterns may play important roles in drought survival and recovery for perennial turfgrass species. However, how whole-plant carbon balance is affected and how responses of carbon relations are involved in plant adaptation to water deficit, particularly in recovery from drought stress for perennial turfgrasses, are not well understood. Understanding how carbon partitioning and accumulation is related to drought survival and recovery is important for developing germplasm of perennial turfgrasses with superior drought tolerance and recuperative potential. Therefore, the objectives of this study were to: 1) examine changes in carbon partitioning and carbohydrate accumulation patterns in shoots and roots in response to drought and re-watering from drought (recovery) for three bentgrass species; and 2) determine whether bentgrass species variation in drought tolerance and recuperative ability is related to differences in carbon partitioning and accumulation patterns.

\section{Materials and Methods}

Plant materials and growth Conditions. Sods of 'Tiger 2' colonial bentgrass, 'L-93' creeping bentgrass, and 'Greenwich' velvet bentgrass were collected from 3-year-old field plots at the Rutgers Turfgrass Horticulture Farm II, North Brunswick, N.J.All three cultivars have been observed to perform well in field trials in the northeastern United States (W.A. Meyer and S.A. Bonos, personal communication), and have been previously utilized for drought performance investigations in the field (DaCosta and Huang, 2006). Plants were washed free of soil and transplanted into polyvinyl chloride (PVC) tubes ( $40 \mathrm{~cm}$ long, $5 \mathrm{~cm}$ diameter) filled with a $3: 1(\mathrm{v} / \mathrm{v})$ sterilized mixture of sandy loam soil (fineloamy, mixed, mesic, Typic Hapludult) and sand. A nylon screen covered the bottom of each PVC tube in order to contain the soil and allow for drainage of water from the tubes.

Plants were initially grown in a greenhouse to allow establishment of turf canopy and root systems. Turf was irrigated four times weekly with tap water to maintain plants under wellwatered conditions, and hand-clipped weekly at $\approx 3-\mathrm{cm}$ height. Full-strength Hoagland's solution (Hoagland and Arnon, 1950) was applied every $14 \mathrm{~d}$ to provide nutrients and facilitate plant establishment prior to initiation of treatments. After approximately $60 \mathrm{~d}$ of establishment in the greenhouse, plants were transferred to a growth chamber $\left(20^{\circ} \mathrm{C}\right.$ day $/ 15^{\circ} \mathrm{C}$ night temperatures, $14 \mathrm{~h}$ of photoperiod, and photosynthetic photon flux density of 600 $\mu \mathrm{mol} \cdot \mathrm{m}^{-2} \cdot \mathrm{s}^{-1}$ ) and allowed to acclimate for $14 \mathrm{~d}$ before treatments were imposed.

Treatments. The experiment consisted of three treatments: 1 ) well-watered control, irrigated with $\approx 200 \mathrm{~mL}$ of tap water five times per week to maintain soil moisture consistently at pot capacity; 2) drought, irrigation completely withheld; and 3) drought recovery, a group of drought-stressed plants were re-watered at the end of the drought treatment and then irrigated with $\approx 200$ $\mathrm{mL}$ of tap water five times per week to maintain soil moisture at pot capacity. The drought treatment was terminated when all of the plants in each container were desiccated and brown (18 d of treatment). At this duration of drought treatment, soil water content declined from $\approx 22 \%$ at pre-stress levels to $8 \%$ water content for all three species (data not shown). Recovery was assessed for $15 \mathrm{~d}$ following rewatering until a majority of plants exhibited turgid leaves and a dense, green canopy. Soil water content was the same for the three bentgrass species during the recovery period (data not shown).

Measurements. Turf quality (TQ) was rated visually based on color (extent of chlorosis and leaf senescence), plant density, and degree of leaf wilting on a 1-9 scale ( 1 = brown, senesced, and desiccated turf; $9=$ fully turgid, green, and dense turf). A rating of 6 indicated the minimal acceptable level of quality based on these characteristics. A quality rating of 6 and above on the 1-9 scale indicated acceptable levels (mostly green or nonchlorotic leaf tissue and little leaf wilting). At the start of the treatments, all plants were rated at the highest turf quality levels (8 or 9) due to fully turgid, green, and dense turf canopies, regardless of any inherent differences in genetic color between the three species.

Changes in leaf water status in response to water deficit were assessed using leaf relative water content (RWC). Previous investigations have demonstrated RWC as a reliable parameter that characterizes water relations of plants and is also closely associated with responses of various physiological and biochemical activities under environmental stresses (Sinclair and Ludlow, 1985). RWC was determined using 10 to 15 fully-expanded leaves randomly sampled from each pot according to Barrs and Weatherley (1962). Leaf samples were detached from the plants and immediately weighed to determine fresh weight (FW). Samples were then placed into small petri dishes filled with water to establish a $100 \%$ relative humidity environment for leaves to reach full hydration. After $\approx 18 \mathrm{~h}$ at $4{ }^{\circ} \mathrm{C}$, leaf samples were removed from water, blotted dry with paper towels, and then weighed immediately to determine turgid weight (TW). Leaf samples were then dried in an oven at $75^{\circ} \mathrm{C}$ for $72 \mathrm{~h}$ to determine dry weight (DW). Leaf 
RWC was calculated as: $(\mathrm{FW}-\mathrm{DW}) /(\mathrm{TW}-\mathrm{DW}) \times 100$.

Partitioning of newly assimilated carbon between shoots and roots was examined using a ${ }^{14} \mathrm{CO}_{2}$ pulse-chase labeling technique (Huang and $\mathrm{Fu}, 2000$ ). Plants were labeled with ${ }^{14} \mathrm{CO}_{2}$ at 0 (prestress), 9, and $15 \mathrm{~d}$ of drought stress, and 6 and $12 \mathrm{~d}$ of recovery. On these labeling dates, shoots were enclosed in a transparent plastic chamber $(18 \mathrm{~cm}$ long $\times 18 \mathrm{~cm}$ wide $\times 10 \mathrm{~cm}$ high $)$ with a 5-cm-diameter opening that was tightly fitted to the PVC plant container. Plants in each container were exposed for $20 \mathrm{~min}$ to $10 \mu \mathrm{Ci}$ of ${ }^{14} \mathrm{CO}_{2}$ that was released from $\mathrm{Na}^{14} \mathrm{CO}_{3}$ by reacting with $85 \%$ lactic acid. ${ }^{14} \mathrm{CO}_{2}$ was circulated through the chamber using a small electric air pump. After the 20-min labeling period, excess ${ }^{14} \mathrm{CO}_{2}$ was absorbed by bubbling the gas through a saturated (12 M) $\mathrm{NaOH}$ solution for $30 \mathrm{~min}$. Four replicated plants of each species for each treatment were labeled at each date. Labeled plants were maintained in the growth chamber for $3 \mathrm{~d}$ to allow for assimilation and distribution of ${ }^{14} \mathrm{CO}_{2}$ throughout the plant (chase period). Following the 3 -d chase period, entire plants (including shoots and roots) were harvested, and roots were washed free of soil at 0,12 , and $18 \mathrm{~d}$ of drought treatment, and 9 and $15 \mathrm{~d}$ of recovery. Shoots were separated into leaves and stem base components (including basal leaf sheaths, crowns, and lateral stems). Leaf, stem, and root samples were frozen in liquid nitrogen and stored at $-20{ }^{\circ} \mathrm{C}$ for $24 \mathrm{~h}$. Samples were then lyophilized using a bench-top freeze dryer (Labconco FreeZone 4.5 Liter Freeze Dry System; Labconco Corp., Kansas City, Mo.) for 48 h, and ground with a mortar and pestle to a fine powder. Leaf, stem, and root dry weights were determined, and samples were stored in sealed glass vials until analysis for ${ }^{14} \mathrm{C}$ activity and carbohydrate content. The ground samples were oxidized with a biological oxidizer (R.J. Harvey Instrument Corp., Hillsdale, N.J.), and the ${ }^{14} \mathrm{C}$ activities in leaves, stems, and roots were determined with a liquid scintillation analyzer (Beckman Liquid Scintillation System; Beckman Instruments, Fullerton, Calif.). The proportion of ${ }^{14} \mathrm{CO}_{2}$ partitioned to leaves, stems, and roots were calculated based on the percent of total newly fixed carbon in the plant.

TNC content was analyzed according to the method described by Ting (1959) with modifications. Briefly, $100 \mathrm{mg}$ of ground samples were transferred to glass tubes containing $2.5 \mathrm{~mL}$ of $5.0 \%$ amylase and incubated at $37^{\circ} \mathrm{C}$ for $24 \mathrm{~h}$. A $0.5-\mathrm{mL}$ aliquot of $0.6 \mathrm{~N} \mathrm{HCL}$ was then added to the solution and incubated at room temperature for another $18 \mathrm{~h}$. To terminate the reaction, $0.31 \mathrm{~mL}$ of $10 \mathrm{~N} \mathrm{NaOH}$ was added and the $\mathrm{pH}$ of the solution was adjusted to between 5 and 7 . Solutions were transferred into $50 \mathrm{~mL}$ round-bottom flasks, volume adjusted to $50 \mathrm{~mL}$ with distilled water, and then shaken so contents were thoroughly distributed. A 1.0-mL aliquot of solution was added to a glass tube containing $1.5 \mathrm{~mL}$ of alkaline ferricyanide reagent, and then placed in a boiling water bath for $10 \mathrm{~min}$. The glass tubes were quickly cooled in an ice bath, and then partially neutralized with $3.0 \mathrm{~mL}$ of $2 \mathrm{~N} \mathrm{H}_{2} \mathrm{SO}_{4}$. Once no further gas was evolved from the solution, $1.2 \mathrm{~mL}$ of arsenomolybdate solution was added and tubes were inverted several times in order to mix the solution thoroughly. Volume was adjusted to $25 \mathrm{~mL}$ with distilled water. The absorbance of the solution was measured at $515 \mathrm{~nm}$ with a spectrophotometer (Spectronic Genesys Series; Spectronic Instruments, Rochester, N.Y.).

EXPERIMENTAL DESIGN AND STATISTICAL ANALYSIS. Plants were arranged in a randomized split-block design with soil moisture treatment as the main plot and species as the sub-plot. There were four blocks, each containing control and drought treatments, and four replicates per species within each of the soil moisture treat- ments. Effects of water treatment, species, organ type, sampling times and corresponding interactions were determined by analysis of variance according to the general linear model procedure of SAS (version 8.2; SAS Institute, Cary, N.C.). Differences between treatment means were separated by the least significant different (LSD) test at the 0.05 probability level.

\section{Results}

TURF QUALITY. TQ for all three species declined rapidly with drought duration. It decreased to 7.2, 5.1, and 6.3 by $12 \mathrm{~d}$ of drought for colonial bentgrass, creeping bentgrass, and velvet bentgrass, respectively; which were lower than respective control plants but most plants were still green and turgid (Fig. 1). At this duration of drought treatment, soil water content declined from $\approx 22 \%$ to $9 \%$ for creeping bentgrass, which was significantly lower $(P \leq$ $0.05)$ than that of colonial bentgrass and velvet bentgrass $(\approx 11 \%$ for both species) (data not shown). By the end of drought period (18 d), plants had a TQ rating of only 2.2, 1.9, and 3.3 for colonial bentgrass, creeping bentgrass, and velvet bentgrass, respectively, with over $90 \%$ of leaves being brown and desiccated. At this time, TQ for colonial bentgrass and creeping bentgrass were the same and significantly lower than that of velvet bentgrass $(P \leq 0.05)$.

Upon re-watering, TQ recovered to levels above the minimal acceptable level (6.0) by $4 \mathrm{~d}$ of re-watering for colonial bentgrass and velvet bentgrass, and by $9 \mathrm{~d}$ for creeping bentgrass (Fig. 1). In general, colonial bentgrass exhibited highest TQ, creeping bentgrass had lowest TQ, and velvet bentgrass exhibited intermediate TQ during the recovery period. TQ for colonial bentgrass recovered to the pre-stress level by $12 \mathrm{~d}$ of the recovery treatment. However, even though TQ for creeping bentgrass and velvet bentgrass exceeded the minimal acceptable quality by $15 \mathrm{~d}$ of recovery, TQ for these two species (7.5 and 7.0, respectively) never returned to the pre-stress level (8.3 and 8.4, respectively) during the study period.

LEAF RELATIVE WATER CONTENT. There were no significant differences in leaf RWC between species under well-watered conditions (all $>94 \%$ RWC), therefore data for the three species was averaged to represent the RWC level of well-watered control plants throughout the experimental period (Fig. 2). Within the first $9 \mathrm{~d}$ of drought treatment, there were no significant declines in RWC, and all three species exhibited the same RWC levels $(\approx 95 \%)$. At $18 \mathrm{~d}$ of drought treatment, RWC declined by $50 \%$ to $70 \%$, depending on species, compared to the control level. Velvet bentgrass exhibited significantly higher RWC than creeping bentgrass ( $47 \%$ vs. $31 \%$, respectively). Colonial bentgrass had intermediate RWC among the three species (38\%). After $5 \mathrm{~d}$ of re-watering, RWC of colonial bentgrass and velvet bentgrass recovered to $\approx 88 \%$, which was significantly higher than RWC of creeping bentgrass (76\%) (Fig. 2). At $12 \mathrm{~d}$ of re-watering, there were no significant differences in RWC among the three species. Leaf RWC did not fully recover to their control levels for any of the species ( $\approx 87 \%$ RWC).

${ }^{14} \mathrm{C}$ PARTitioning. Carbon partitioning between leaves, stems, and roots changed with drought stress duration. ${ }^{14} \mathrm{C}$ partitioned to roots of colonial bentgrass, creeping bentgrass, and velvet bentgrass increased from $28 \%, 38 \%$, and $23 \%$, respectively, at the pre-stress level ( $0 \mathrm{~d})$ to $43 \%, 53 \%$, and $42 \%$, respectively, at $12 \mathrm{~d}$ of drought treatment (Table 1). At this duration of drought treatment, the proportion of ${ }^{14} \mathrm{C}$ partitioned to roots was significantly greater than that to leaves and stems for all three species. In general, the proportion of ${ }^{14} \mathrm{C}$ partitioned to roots were highest, 


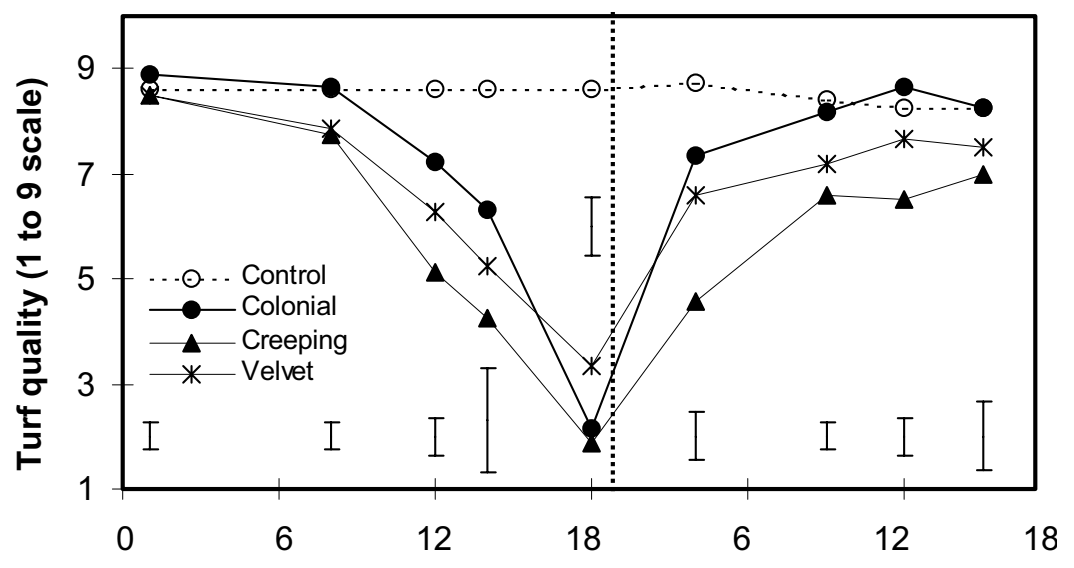

Duration of drought (d)

Duration of recovery (d)

Fig. 1. Changes in turfgrass quality (TQ) during drought stress and re-watering for colonial bentgrass, creeping bentgrass, and velvet bentgrass. A value of 9 represents the best quality (green, dense canopy) and 1 represents the lowest quality (brown, desiccated). There were no differences in TQ between the species under well-watered conditions; therefore, TQ was averaged for the three species to represent a control value under well-watered conditions. The dashed line separates the drought and recovery treatments, and represents the first day of re-watering in which the recovery period was initiated. Vertical bars are LSD values $(P \leq 0.05)$ indicating statistically significant differences for species comparisons at a given day of treatment.

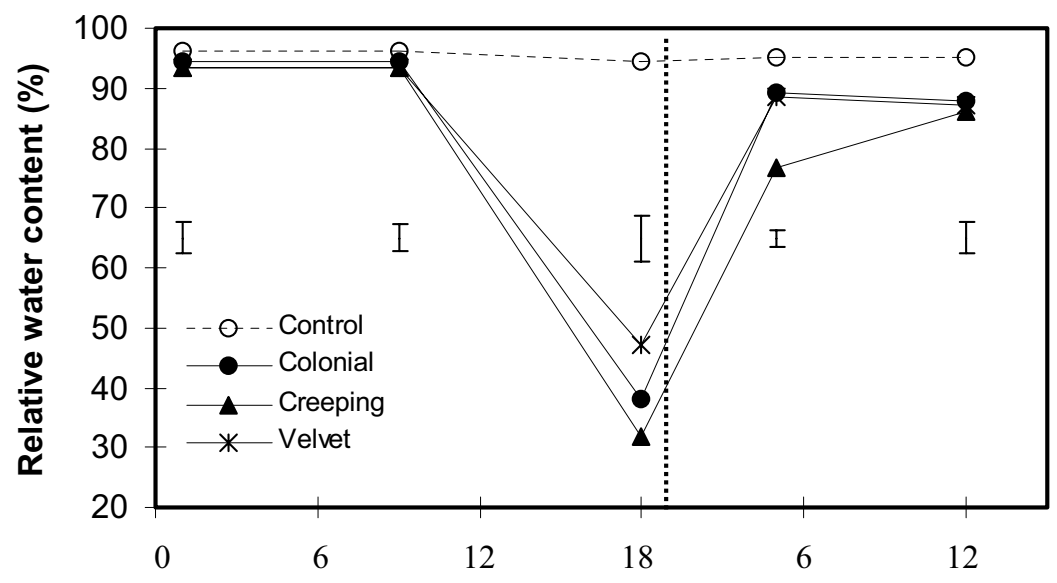

Duration of drought (d)

Duration of recovery $(d)$

Fig. 2. Changes in leaf relative water content (RWC) during drought stress and re-watering for colonial bentgrass, creeping bentgrass, and velvet bentgrass. Control RWC data were averages of three species under well-watered conditions. The dashed line separates the drought and rewatering treatments, and represents the first day of re-watering in which the recovery period was initiated. Vertical bars are LSD values $(P \leq 0.05)$ indicating statistically significant differences for species comparisons at a given day of treatment.

intermediate for stems, and least for leaves for all three species at $12 \mathrm{~d}$ of drought treatment.

Following $18 \mathrm{~d}$ of drought, ${ }^{14} \mathrm{C}$ partitioning to roots significantly declined to $27 \%, 24 \%$, and $26 \%$ compared to $43 \%, 53 \%$, and $42 \%$ that was observed at $12 \mathrm{~d}$ of drought stress for colonial bentgrass, creeping bentgrass, and velvet bentgrass, respectively (Table 1). In contrast, greater proportion of ${ }^{14} \mathrm{C}$ was either partitioned to leaves in colonial bentgrass or to stems in velvet bentgrass; the proportion of ${ }^{14} \mathrm{C}$ did not exhibit significant differences in leaves and stems of creeping bentgrass. Table 2 shows ${ }^{14} \mathrm{C}$ partitioning patterns of well-watered and severely-stressed plants at $18 \mathrm{~d}$ of treatment. There was greater ${ }^{14} \mathrm{C}$ partitioned in leaves for droughtstressed colonial bentgrass (45\%), creeping bentgrass (38\%), and velvet bentgrass (28\%) compared to well-watered plants (29\%, $22 \%$, and $16 \%$, respectively) (Table 2 ). Drought-stressed creeping bentgrass and velvet bentgrass at $18 \mathrm{~d}$ also exhibited decreased ${ }^{14} \mathrm{C}$ partitioning to roots compared to wellwatered plants.

After $9 \mathrm{~d}$ of re-watering, the proportion of ${ }^{14} \mathrm{C}$ partitioned to leaves of colonial bentgrass decreased, while that partitioned to stems increased compared to the pre-recovery level (18 d of drought treatment) (Table 1). There were no significant changes in ${ }^{14} \mathrm{C}$ partitioning patterns for creeping bentgrass and velvet bentgrass between $18 \mathrm{~d}$ of drought and $9 \mathrm{~d}$ of re-watering. The general partitioning patterns for all three species at $9 \mathrm{~d}$ of re-watering was as follows: stems $>$ leaves $>$ roots. At $15 \mathrm{~d}$ of re-watering, there were no significant changes in ${ }^{14} \mathrm{C}$ partitioning for colonial bentgrass and velvet bentgrass, but there was decreased ${ }^{14} \mathrm{C}$ partitioned to leaves for creeping bentgrass. The general pattern for ${ }^{14} \mathrm{C}$ partitioning for colonial bentgrass and creeping bentgrass at $15 \mathrm{~d}$ of recovery was as follows: stems $>$ leaves $=$ roots. For velvet bentgrass, stems $\geq$ leaves $\geq$ roots.

${ }^{14} \mathrm{C}$ partitioning in well-watered and severelystressed plants (18 d of drought) at $15 \mathrm{~d}$ of recovery treatment is presented in Table 2. Compared to wellwatered plants, previously drought-stressed plants of creeping bentgrass exhibited greater ${ }^{14} \mathrm{C}$ partitioning to stems (50\% vs. $37 \%$ for control plants) following $15 \mathrm{~d}$ of re-watering. At this time, both colonial bentgrass and creeping bentgrass exhibited less ${ }^{14} \mathrm{C}$ partitioning to roots compared to roots of well-watered plants. There were no differences in the proportion of ${ }^{14} \mathrm{C}$ partitioned to leaves, stems, and roots between well-watered and previously stressed plants of velvet bentgrass at $15 \mathrm{~d}$ of re-watering.

TOTAL NONSTRUCTURAL CARBOHYDRATE CONTENT. TNC content in leaves, stems, and roots was not significantly different for colonial bentgrass and creeping bentgrass before drought stress was imposed ( 0 d); for velvet bentgrass, TNC content in stems (103 $\left.\mathrm{mg} \cdot \mathrm{g}^{-1}\right)$ was higher than that in leaves $\left(88 \mathrm{mg} \cdot \mathrm{g}^{-1}\right)$ and roots $\left(85 \mathrm{mg}^{-\mathrm{g}^{-1}}\right)$ (Table 3 ). At $12 \mathrm{~d}$ of drought treatment, there was a $20 \%$ to $40 \%$ increase in leaf, stem, and root TNC levels for colonial bentgrass and creeping bentgrass compared to the pre-stress levels. For velvet bentgrass exposed to $12 \mathrm{~d}$ of drought, leaf TNC content increased by $38 \%$, but stem and root TNC content were not significantly different from pre-stress levels. In general, TNC content in leaves was $25 \%, 35 \%$, and $31 \%$ greater than that in roots for colonial bentgrass, creeping bentgrass, and velvet bentgrass, respectively, at $12 \mathrm{~d}$ of drought treatment.

By $18 \mathrm{~d}$ of drought treatment, leaf TNC content remained higher than the pre-stress levels in all three species (Table 3). Comparing TNC content among different organs, TNC content was greatest in leaves, intermediate in stems, and lowest in roots for all three species when exposed to $18 \mathrm{~d}$ of drought. Table 4 shows TNC content of well-watered and drought-stressed plants at $18 \mathrm{~d}$ of treatment. Compared to well-watered plants, there was also greater TNC content in leaves of drought-stressed plants for all three species, which were $13 \%, 25 \%$, and $24 \%$ higher in drought-stressed plants of colonial bentgrass, creeping bentgrass, and velvet bentgrass, respectively (Table 4). Additionally, colonial bentgrass and velvet bentgrass exhibited significantly greater 
Table 1. Proportion of newly photosynthesized ${ }^{14} \mathrm{C}$ partitioned to leaves, stems, and roots during drought stress and recovery for colonial bentgrass, creeping bentgrass, and velvet bentgrass. Data are presented are for assessment of ${ }^{14} \mathrm{C}$ partitioning at 0 (pre-stress), 12, and $18 \mathrm{~d}$ of drought treatment, and 9 and $15 \mathrm{~d}$ of recovery treatment. Values followed by the same lowercase letter within a column for each species indicate no significant differences in ${ }^{14} \mathrm{C}$ partitioned between different plant organs $(P \leq 0.05)$ based on a LSD test. Values followed by the same uppercase letter within a row for each organ type indicate no significant differences in ${ }^{14} \mathrm{C}$ partitioned across different dates of treatment $(P \geq 0.05)$ based on a LSD test.

\begin{tabular}{|c|c|c|c|c|c|c|}
\hline \multirow{3}{*}{$\begin{array}{l}\text { Bentgrass } \\
\text { species }\end{array}$} & \multirow{3}{*}{$\begin{array}{l}\text { Organ } \\
\text { type }\end{array}$} & \multicolumn{5}{|c|}{ Proportion of newly photosynthesized ${ }^{14} \mathrm{C}(\%)$} \\
\hline & & \multicolumn{3}{|c|}{ Drought treatment } & \multicolumn{2}{|c|}{ Recovery } \\
\hline & & $0 \mathrm{~d}$ & $12 \mathrm{~d}$ & $18 \mathrm{~d}$ & $9 \mathrm{~d}$ & $15 \mathrm{~d}$ \\
\hline \multirow[t]{3}{*}{ Colonial } & Leaves & $31.3 \mathrm{~b} \mathrm{BC}$ & 23.9 c C & 44.9 a $\mathrm{A}$ & $34.8 \mathrm{~b} \mathrm{~B}$ & $30.9 \mathrm{~b} \mathrm{BC}$ \\
\hline & Stems & $40.3 \mathrm{a} \mathrm{A}$ & $33.0 \mathrm{~b} \mathrm{AB}$ & $28.1 \mathrm{~b} \mathrm{~B}$ & $41.5 \mathrm{a} \mathrm{A}$ & $40.0 \mathrm{a} A$ \\
\hline & Roots & $28.4 \mathrm{~b} \mathrm{~B}$ & $43.1 \mathrm{a} \mathrm{A}$ & $27.0 \mathrm{~b} \mathrm{~B}$ & 24.7 c B & $29.1 \mathrm{~b} \mathrm{~B}$ \\
\hline \multirow[t]{3}{*}{ Creeping } & Leaves & $32.5 \mathrm{a} \mathrm{A}$ & $17.0 \mathrm{c} \mathrm{B}$ & $38.2 \mathrm{a} \mathrm{A}$ & $34.2 \mathrm{~b} \mathrm{~A}$ & $25.1 \mathrm{~b} \mathrm{~B}$ \\
\hline & Stems & 30.0 a CD & 29.9 b D & 37.9 a BC & $43.1 \mathrm{a} \mathrm{AB}$ & 50.1 a A \\
\hline & Roots & 37.5 a B & $53.1 \mathrm{a} \mathrm{A}$ & $23.9 \mathrm{~b} \mathrm{C}$ & 22.7 c C & $24.8 \mathrm{~b} \mathrm{C}$ \\
\hline \multirow[t]{3}{*}{ Velvet } & Leaves & $27.0 \mathrm{~b} \mathrm{AB}$ & $25.1 \mathrm{c} \mathrm{B}$ & $28.3 \mathrm{~b} \mathrm{AB}$ & $34.5 \mathrm{~b} \mathrm{~A}$ & $33.1 \mathrm{ab} \mathrm{A}$ \\
\hline & Stems & $50.2 \mathrm{a} \mathrm{A}$ & $32.5 \mathrm{~b} \mathrm{C}$ & 46.6 a A & $43.9 \mathrm{a} \mathrm{AB}$ & 38.8 a BC \\
\hline & Roots & $22.8 \mathrm{~b} \mathrm{~B}$ & $42.4 \mathrm{a} \mathrm{A}$ & $26.1 \mathrm{~b} \mathrm{~B}$ & $22.6 \mathrm{c} \mathrm{B}$ & $28.1 \mathrm{~b} \mathrm{~B}$ \\
\hline
\end{tabular}

Table 2. Comparison of ${ }^{14} \mathrm{C}$ partitioning between well-watered control and stressed plants of colonial bentgrass, creeping bentgrass, and velvet bentgrass at $18 \mathrm{~d}$ of drought treatment and $15 \mathrm{~d}$ of recovery treatment. Columns marked with the same letters within a species are not significantly different $(P \geq 0.05)$ based on a LSD test.

\begin{tabular}{|c|c|c|c|c|c|c|c|}
\hline \multirow{3}{*}{$\begin{array}{l}\text { Bentgrass } \\
\text { species }\end{array}$} & \multirow[b]{3}{*}{ Treatment } & \multicolumn{6}{|c|}{ Proportion of newly photosynthesized ${ }^{14} \mathrm{C}(\%)$} \\
\hline & & \multicolumn{3}{|c|}{$18 \mathrm{~d}$ drought } & \multicolumn{3}{|c|}{$15 \mathrm{~d}$ recovery } \\
\hline & & Leaves & Stems & Roots & Leaves & Stems & Roots \\
\hline \multirow[t]{2}{*}{ Colonial } & Control & $29.3 \mathrm{~b}$ & $41.7 \mathrm{a}$ & $29.0 \mathrm{a}$ & $22.1 \mathrm{a}$ & $39.0 \mathrm{a}$ & $38.9 \mathrm{a}$ \\
\hline & Drought & $44.9 \mathrm{a}$ & $28.1 \mathrm{~b}$ & $27.0 \mathrm{a}$ & $30.9 \mathrm{a}$ & $40.0 \mathrm{a}$ & $29.1 \mathrm{a}$ \\
\hline \multirow[t]{2}{*}{ Creeping } & Control & $22.2 \mathrm{~b}$ & $46.7 \mathrm{a}$ & $31.1 \mathrm{a}$ & $23.3 \mathrm{a}$ & $36.7 \mathrm{~b}$ & $40.0 \mathrm{a}$ \\
\hline & Drought & $38.2 \mathrm{a}$ & 37.9 a & $23.9 \mathrm{~b}$ & $25.1 \mathrm{a}$ & $50.1 \mathrm{a}$ & $24.8 \mathrm{~b}$ \\
\hline \multirow[t]{2}{*}{ Velvet } & Control & $16.2 \mathrm{~b}$ & $38.7 \mathrm{~b}$ & $45.1 \mathrm{a}$ & $28.0 \mathrm{a}$ & $33.1 \mathrm{a}$ & $38.9 \mathrm{a}$ \\
\hline & Drought & $28.3 \mathrm{a}$ & $46.6 \mathrm{a}$ & $26.1 \mathrm{~b}$ & $33.1 \mathrm{a}$ & $38.8 \mathrm{a}$ & $28.1 \mathrm{a}$ \\
\hline
\end{tabular}

Table 3. Total nonstructural carbohydrate (TNC) content in leaves, stems, and roots during drought stress and recovery for colonial bentgrass, creeping bentgrass, and velvet bentgrass. Data presented are for assessment of TNC content at 0 (pre-stress), 12, and $18 \mathrm{~d}$ of drought treatment, and 9 and $15 \mathrm{~d}$ of recovery treatment. Values followed by the same lowercase letter within a column for each species indicate no significant differences in TNC content between different plant organs $(P \leq 0.05)$ based on a LSD test. Values followed by the same uppercase letter within a row for each organ type indicate no significant differences in TNC content across different dates of treatment $(P \geq 0.05)$ based on a LSD test.

\begin{tabular}{|c|c|c|c|c|c|c|}
\hline \multirow{3}{*}{$\begin{array}{l}\text { Bentgrass } \\
\text { species }\end{array}$} & \multirow{3}{*}{$\begin{array}{l}\text { Organ } \\
\text { type }\end{array}$} & \multicolumn{5}{|c|}{ TNC content $\left(\mathrm{mg} \cdot \mathrm{g}^{-1}\right.$ dry matter $)$} \\
\hline & & \multicolumn{3}{|c|}{ Drought treatment } & \multicolumn{2}{|c|}{ Recovery } \\
\hline & & $0 \mathrm{~d}$ & $12 \mathrm{~d}$ & $18 \mathrm{~d}$ & $9 \mathrm{~d}$ & $15 \mathrm{~d}$ \\
\hline \multirow[t]{3}{*}{ Colonial } & Leaves & 98.0 a B & $148.4 \mathrm{a} \mathrm{A}$ & $141.4 \mathrm{a} \mathrm{A}$ & 114.0 a B & 109.3 a B \\
\hline & Stems & 93.7 a B & $135.9 \mathrm{ab} \mathrm{A}$ & 97.7 b B & 86.8 b BC & $71.4 \mathrm{~b} \mathrm{C}$ \\
\hline & Roots & 67.7 a BC & $112.1 \mathrm{~b} \mathrm{~A}$ & 73.9 c B & $56.3 \mathrm{c} \mathrm{CD}$ & $46.5 \mathrm{c} \mathrm{D}$ \\
\hline \multirow[t]{3}{*}{ Creeping } & Leaves & 95.3 a C & 159.7 a A & $156.3 \mathrm{a} \mathrm{A}$ & 115.4 a B & 106.2 a BC \\
\hline & Stems & 93.6 a B & $117.1 \mathrm{~b} \mathrm{~A}$ & 119.7 b A & $92.4 \mathrm{~b} \mathrm{~B}$ & $79.9 \mathrm{ab} C$ \\
\hline & Roots & 75.4 a B & $103.1 \mathrm{~b} \mathrm{~A}$ & $83.8 \mathrm{c} \mathrm{B}$ & $75.6 \mathrm{~b} \mathrm{~B}$ & $57.6 \mathrm{~b} \mathrm{C}$ \\
\hline \multirow[t]{3}{*}{ Velvet } & Leaves & 87.7 b B & $140.5 \mathrm{a} \mathrm{A}$ & $147.1 \mathrm{a} \mathrm{A}$ & 108.7 a B & 107.4 a B \\
\hline & Stems & $102.6 \mathrm{a} \mathrm{AB}$ & 124.7 a A & $121.7 \mathrm{~b} \mathrm{~A}$ & 87.6 b BC & $66.1 \mathrm{~b} \mathrm{C}$ \\
\hline & Roots & $85.0 \mathrm{~b} \mathrm{AB}$ & $96.7 \mathrm{~b} \mathrm{~A}$ & $96.2 \mathrm{c} \mathrm{A}$ & $81.9 \mathrm{~b} \mathrm{AB}$ & $72.7 \mathrm{~b} \mathrm{~B}$ \\
\hline
\end{tabular}

Table 4. Comparison of total nonstructural carbohydrate (TNC) content between well-watered control and stressed plants of colonial bentgrass, creeping bentgrass, and velvet bentgrass at $18 \mathrm{~d}$ of drought treatment and $15 \mathrm{~d}$ of recovery treatment. Columns marked with the same letters within a species are not significantly different $(P \geq$ 0.05 ) based on a LSD test.

\begin{tabular}{|c|c|c|c|c|c|c|c|}
\hline \multirow{3}{*}{$\begin{array}{l}\text { Bentgrass } \\
\text { species }\end{array}$} & \multirow[b]{3}{*}{ Treatment } & \multicolumn{6}{|c|}{ TNC content $\left(\mathrm{mg} \cdot \mathrm{g}^{-1}\right.$ dry matter $)$} \\
\hline & & \multicolumn{3}{|c|}{$18 \mathrm{~d}$ drought } & \multicolumn{3}{|c|}{$15 \mathrm{~d}$ recovery } \\
\hline & & $\overline{\text { Leaves }}$ & Stems & Roots & Leaves & Stems & Roots \\
\hline \multirow[t]{2}{*}{ Colonial } & Control & $122.6 \mathrm{~b}$ & $73.3 \mathrm{~b}$ & $70.4 \mathrm{a}$ & $106.1 \mathrm{a}$ & $57.0 \mathrm{a}$ & $56.0 \mathrm{a}$ \\
\hline & Drought & $141.4 \mathrm{a}$ & $97.7 \mathrm{a}$ & $73.9 \mathrm{a}$ & $109.3 \mathrm{a}$ & $71.4 \mathrm{a}$ & $46.5 \mathrm{a}$ \\
\hline \multirow[t]{2}{*}{ Creeping } & Control & $116.7 \mathrm{~b}$ & $107.9 \mathrm{a}$ & $75.1 \mathrm{a}$ & $115.3 \mathrm{a}$ & $84.2 \mathrm{a}$ & $64.6 \mathrm{a}$ \\
\hline & Drought & $156.3 \mathrm{a}$ & $119.7 \mathrm{a}$ & $83.8 \mathrm{a}$ & $106.2 \mathrm{a}$ & $79.9 \mathrm{a}$ & $57.6 \mathrm{a}$ \\
\hline \multirow[t]{2}{*}{ Velvet } & Control & $112.3 \mathrm{~b}$ & $97.6 \mathrm{~b}$ & $87.4 \mathrm{a}$ & $102.9 \mathrm{a}$ & $81.3 \mathrm{a}$ & $76.2 \mathrm{a}$ \\
\hline & Drought & $147.1 \mathrm{a}$ & $121.7 \mathrm{a}$ & $96.2 \mathrm{a}$ & $107.4 \mathrm{a}$ & $66.1 \mathrm{a}$ & $72.7 \mathrm{a}$ \\
\hline
\end{tabular}


TNC content in stems of drought-stressed plants than that of well-watered plants. No differences were observed in root TNC content between well-watered and drought-stressed plants for all three species.

Upon re-watering, TNC content decreased in leaves, stems, and roots at $9 \mathrm{~d}$ of re-watering compared to the pre-recovery level at $18 \mathrm{~d}$ of drought stress for colonial bentgrass, creeping bentgrass, and velvet bentgrass (Table 3). Similar to what was observed at 12 and $18 \mathrm{~d}$ of drought treatment, leaves accumulated the greatest TNC content, and stems and roots had lower TNC at $9 \mathrm{~d}$ of re-watering. At $15 \mathrm{~d}$ of re-watering, TNC content in leaves, stems, and roots remained similar to that at $9 \mathrm{~d}$ of re-watering for colonial bentgrass and velvet bentgrass. For creeping bentgrass, TNC content was the same in leaves but lower in stems and roots at $9 \mathrm{~d}$ of re-watering compared to that at $15 \mathrm{~d}$ of re-watering. In general, TNC content was greatest in leaves and lower in stems and roots for all three species during recovery. Table 4 shows TNC content of well-watered and previously drought-stressed plants at $15 \mathrm{~d}$ of re-watering treatment; there were no differences in leaf, stem, and root TNC content between well-watered and previously drought-stressed plants (Table 4).

\section{Discussion}

Soil drying resulted in significant decline in TQ and leaf RWC for all three bentgrass species; however, velvet bentgrass maintained higher TQ and RWC at the end of the drought period, compared to colonial bentgrass and creeping bentgrass. Upon rewatering following drought stress, RWC for colonial bentgrass and velvet bentgrass recovered to higher levels and more rapidly than that of creeping bentgrass, and colonial bentgrass exhibited the highest TQ during the recovery period. RWC is a measure of water deficit in the leaf and TQ represents the general performance of turfgrass canopy. Species variation in RWC and TQ responses to drought and re-watering indicated that among three bentgrass species, velvet bentgrass was relatively more tolerant to drought stress while colonial bentgrass had the best recuperative ability. Species and/or cultivar differences in resistance to drought as well as extent of recovery from drought have been associated with various morphological, physiological, and biochemical factors, including changes in root size, distribution, and viability (Bonos and Murphy, 1999; Qian et al., 1997), stability of the photosynthetic apparatus and photochemical efficiency (Abraham et al., 2004), membrane stability (Jiang and Huang, 2001), osmotic adjustment (Elmi and West, 1995; White et al., 1992), and phytohormone accumulation (Wang and Huang, 2003). The results from this study suggest that bentgrass species differences in drought survival and recovery could be related to changes in carbon partitioning and carbohydrate accumulation patterns, as discussed in the following sections.

Carbon distribution in plants can be evaluated using ${ }^{14} \mathrm{CO}_{2}$ labeling techniques, whereby the specific activities of the carbon fractions in different plant tissues are followed using radioisotopes (Krans and Beard, 1980; Meharg and Killham, 1989; Warembourg and Estelrich, 2001). This technique may provide insight into the partitioning pattern of newly photosynthesized carbon to shoots and roots, as well as how partitioning patterns are affected by factors such as water availability. In the present study, the proportion of newly photosynthesized ${ }^{14} \mathrm{C}$ partitioned to roots of colonial bentgrass, creeping bentgrass, and velvet bentgrass increased significantly during the early phase of drought stress (12 d) prior to severe water deficit and turf damage. At this time,
${ }^{14} \mathrm{C}$ partitioning was generally greatest to roots, intermediate to stems, and lowest to leaves for all three bentgrass species. This carbon partitioning pattern agrees with previous investigations on root adaptive mechanisms under drought stress for other species. Greater carbon partitioning to roots may facilitate root growth and water acquisition during drought stress. Water deficit resulted in $15 \%$ to $30 \%$ greater ${ }^{14} \mathrm{C}$ partitioning to roots of tall fescue under low nitrogen treatment, and $6 \%$ to $13 \%$ higher under high nitrogen (Onillon et al., 1995). Huang and Gao (2000) reported that soil drying resulted in increased proportion of ${ }^{14} \mathrm{C}$ partitioned to roots for drought-tolerant cultivars of tall fescue. Greater investment of carbon to roots in velvet bentgrass could contribute to its maintenance of higher water content and turf quality during prolonged periods of drought, compared to colonial bentgrass and creeping bentgrass.

As drought progressed, there was a shift in ${ }^{14} \mathrm{C}$ partitioning from roots to leaves and stems. When severe water deficit and turf quality declines occurred at $18 \mathrm{~d}$ of drought stress, droughtstressed plants exhibited $\approx 35 \%$ to $45 \%$ greater ${ }^{14} \mathrm{C}$ partitioning to leaves for all three species. Similar to ${ }^{14} \mathrm{C}$ partitioning patterns, leaf TNC content was $15 \%$ to $25 \%$ greater in severely droughtstressed plants compared to well-watered controls. Decreased utilization of carbohydrates due to inhibition of shoot growth could be related to the accumulation of carbohydrates in leaves under drought. TNC concentrations were found to be higher in leaves of drought-stressed plants compared to leaves of well-watered plants for three tall fescue cultivars (Huang and Gao, 2000). Increases in carbohydrate content of shoots have also been observed for D. glomerata (Brown and Blazer, 1970; Volaire, 1994) and other cool-season grasses (Busso et al., 1990).

Stem TNC content was also significantly greater for droughtstressed plants of colonial bentgrass and velvet bentgrass following prolonged drought stress, whereas no differences in stem TNC content were observed between drought-stressed and well-watered creeping bentgrass. Greater accumulation of carbohydrates in leaf and stem bases has been associated with improved recovery following drought stress (Turner, 1990; Volaire, 1995). Increases in TNC may contribute to osmotic adjustment to sustain turgor and meristem viability under desiccation, or may also serve as substrates for biosynthesis following drought stress (Qian and Fry, 1997; White et al., 1992). Nicolas et al. (1985) reported that a drought-tolerant cultivar of wheat (Triticum aestivum L.) accumulated three times more carbohydrate reserves in stems than the drought-sensitive cultivar, which was related to better recovery after drought. Our data suggest that greater accumulation of TNC in stems of colonial bentgrass and velvet bentgrass could be related to more rapid recovery of TQ and leaf RWC, compared to creeping bentgrass that did not exhibit increased stem TNC accumulation during drought stress relative to wellwatered plants. TNC content in leaves, stems, and roots returned to the well-watered level following $15 \mathrm{~d}$ of re-watering, which was corresponded with the complete recovery in RWC and turf quality. These results indicated that all three bentgrass species were able to recover physiologically from drought stress following prolonged period of rewatering. In addition, the reduction in TNC content during recovery could be due to increases in carbohydrate demand or usage resulted from rapid recovery in growth and physiological activities as shown by increased turf quality and RWC.

In summary, this study demonstrated that the partitioning of newly photosynthesized carbon and carbohydrate status in different organs of colonial bentgrass, creeping bentgrass, and velvet 
bentgrass changed with drought stress duration and re-watering following drought stress. The partitioning of ${ }^{14} \mathrm{C}$ increased in roots during the early phase of drought stress, which may serve as a short-term drought adaptive mechanism for the three bentgrass species. During prolonged drought, carbon partitioning shifted toward leaves and stems, and there was significant leaf and stem accumulation of TNC, particularly of colonial bentgrass and velvet bentgrass. The accumulation and storage of TNC during severe drought may either contribute to osmotic adjustment and survival of meristematic regions, and/or serve as reserves, thus contributing to plant regrowth once drought stress is alleviated. Management practices that promote carbon allocation for root growth prior to severe drought stress can result in improved drought persistence, such as deep and infrequent irrigation, avoiding excessive nitrogen application, and maintaining optimum levels of phosphorus and potassium fertilization. Raising the mowing height or reducing frequency of mowing under water deficit also may promote carbohydrate accumulation, thus enhancing rapid recovery following drought stress. Breeding for drought survival and high recuperative ability of turfgrasses, as related to efficient carbon partitioning and utilization, would be valuable for selection of grasses with enhanced adaptation to water-limited environments.

\section{Literature Cited}

Abraham, E.M., B. Huang, S.A. Bonos, and W.A. Meyer. 2004. Evaluation of drought resistance for texas bluegrass, kentucky bluegrass, and their hybrids. Crop Sci. 44:1746-1753.

Assuero, S.G., C. Matthew, P. Kemp, D.J. Barker, and A. Mazzanti. 2002. Effects of water deficit on Mediterranean and temperate cultivars on tall fescue. Austral. J. Agr. Res. 53:29-40.

Barrs, H.D. and P.E. Weatherley. 1962. A re-examination of the relative turgidity technique for estimating water deficit in leaves. Austral. J. Biol. Sci. 15:413-428.

Bonos, S.A. and J.A. Murphy. 1999. Growth responses and performance of kentucky bluegrass under summer stress. Crop Sci. 39:770-774.

Bradford, K.J. and T.C. Hsiao. 1982. Physiological responses to moderate water stress, p. 263-324. In: O.L. Lange, P.S. Nobel, C.B. Osmond, and H.Ziegler(eds.). Physiological plant ecology, vol. 12b. Springer-Verlag, Berlin, Germany.

Brown, R.H. and R.E. Blazer. 1970. Soil moisture and temperature effects on growth and soluble carbohydrates of orchard grass (Dactylis glomerata). Crop Sci. 10:213-216.

Busso, C.A., J.H. Richards, and N.J. Chatterton. 1990. Nonstructural carbohydrates and spring regrowth of two cool-season grasses: Interaction of drought and clipping. J. Range Mgt. 43:336-343.

Chaves, M.M. 1991. Effects of water deficits on carbon assimilation. J. Expt. Bot. 42:1-16.

DaCosta, M. and B. Huang. 2006. Minimum water requirements for creeping, colonial, and velvet bentgrasses under fairway conditions. Crop Sci. 46: 81-89.

Elmi, A.A. and C.P. West. 1995. Endophyte infection effects on stomatal conductance, osmotic adjustment and drought recover of tall fescue. New Phytol. 131:61-67.

Godde, D. 1999. Adaptations of the photosynthetic apparatus to stress conditions, p. 449-474. In: H.R. Lerner (ed.). Plant responses to environmental stresses. Marcel Dekker, New York.

Hamblin, A., D. Tennant, and M.W. Perry. 1990. The cost of stress: Dry matter partitioning changes with seasonal supply of water and nitrogen to dryland wheat. Plant Soil 122:47-58.

Hoagland, D.R. and D.I. Arnon. 1950. The water-culture method for growing plants without soil, p. 31. California Agr. Expt. Sta. Circ. 347. College of Agriculture, Univ. of California, Berkeley.

Hsiao, T.C. 1973. Plant responses to water stress. Annu. Rev. Physiol. 24:519570 .

Huang, B. and J. Fu. 2000. Photosynthesis, respiration, and carbon allocation of two cool-season perennial grasses in response to surface soil drying. Plant Soil 227:17-26.

Huang, B. and H. Gao. 2000. Root physiological characteristics associated with drought resistance in tall fescue cultivars. Crop Sci. 40:196-203.

Hull, R.J. 1992. Energy relations and carbohydrate partitioning in turfgrass, p. 175-205. In: D.V. Waddington, R.N. Carrow, and R.C. Shearman (eds.). Turfgrass, vol. 32. Amer. Soc. Agron., Madison, Wis.
Jiang, Y. and B. Huang. 2001. Drought and heat stress injury to two cool-season turfgrasses in relation to antioxidant metabolism and lipid peroxidation. Crop Sci. 41:436-442.

Kalapos, T., R. Van den Boogaard, and H. Lambers. 1996. Effect of soil drying on growth, biomass allocation and leaf gas exchange of two annual grass species. Plant Soil 185:137-149.

Krans, J.V. and J.B. Beard. 1980. The effects of stage of seedling development on selected physiological and morphology parameters in kentucky bluegrass and red fescue. Proc. Third Intl. Turfgrass Res. Conf., Munich, Germany, 11-13 July 1977. p. 89-95.

Meharg, A.A. and K. Killham. 1989. Distribution of assimilated carbon within the plant and rhizosphere of Lolium perenne: Influence of temperature. Soil Biol. Biochem. 21:487-489.

Mooney, H.A. and W.E. Winner. 1991. Partitioning response of plants to stress, p. 129-141. In: H.A. Mooney, W.E. Winner, and E.J. Pell (eds.). Response of plants to multiple stresses. Academic, San Diego, Calif.

Narra, S., T.W. Fermanian, J.M. Swiader, T.B. Voigt, and B.E. Branham. 2004. Total nonstructural carbohydrate assessment in creeping bentgrass at different mowing heights. Crop Sci. 44:908-913.

Nicolas, M.E., H. Lambers, R.J. Simpson, and M.J. Dalling. 1985. Effect of drought on metabolism and partitioning of carbon in two wheat varieties differing in drought-tolerance. Ann. Bot. 55:727-742.

Onillon, B., J.L. Durand, F. Gastal, and R. Tournebize. 1995. Drought effects on growth and carbon partitioning in a tall fescue sward grown at different rates of nitrogen fertilization. European J. Agron. 4:91-99.

Oosthuizen, I.B. and H.A. Snyman. 2001. The influence of water stress on nonstructural carbohydrate concentration in Themeda triandra. South African J. Bot. 67:53-57.

Qian, Y. and J.D. Fry. 1997. Water relations and drought tolerance of four turfgrasses. J. Amer. Soc. Hort. Sci. 122:129-133.

Qian, Y.L., J.D. Fry, and W.S. Upham. 1997. Rooting and drought avoidance of warm-season turfgrasses and tall fescue in Kansas. Crop Sci. 37:905-910.

Richardson, M.D., J. Chapman, G.W., C.S. Hoveland, and C.W. Bacon. 1992. Sugar alcohols in endophyte-infected tall fescue under drought. Crop Sci. 32:1060-1061.

Sheffer, K.M., T.L. Watschke, and J.M. Duich. 1979. Carbohydrate sampling in kentucky bluegrass turf. Agron. J. 71:301-304.

Simane, B., J.M. Peacock, and P.C. Struik. 1993. Differences in developmental plasticity and growth rate among drought-resistant and susceptible cultivars of durum wheat (Triticum turgidum L. var. durum). Plant Soil 157:155-166.

Sinclair, T.R. and Ludlow, M.M. 1985. Who taught plants thermodynamics? The unfulfilled potential of plant water potential. Austal. J. Plant Physiol. 12:213-217.

Spollen, W.G. and C.J. Nelson. 1994. Response of fructan to water deficit in growing leaves of tall fescue. Plant Physiol. 106:329-336.

Suzuki, M. 1993. Fructans in crop production and preservation, p. 227-256. In: M. Suzuki and N.J. Chatterton (eds.). The science and technology of fructans. CRC Press, Boca Raton, Fla.

Ting, S.V. 1959. Rapid colorimetric methods for simultaneous determination of total reducing sugars and fructose in citrus juices. Fruit Juice Assn. 4:263-266.

Turner, L.B. 1990. The extent and pattern of osmotic adjustment in white clover (Trifolium repens L.) during the development of water stress. Ann. Bot. 66:721-777.

Volaire, F. 1994. Effects of summer drought and spring defoliation on carbohydrate reserves, persistence and recovery of two populations of cocksfoot (Dactylis glomerata) in a Mediterranean environment. J. Agr. Sci. 122:207-215.

Volaire, F. 1995. Growth, carbohydrate reserves and drought survival strategies of contrasting Dactylis glomerata populations in a Mediterranean environment. J. Appl. Ecol. 32:56-66.

Volaire, F., H. Thomas, and F. Lelievre. 1998. Survival and recovery of perennial forage grasses under prolonged Mediterranean drought. New Phytol. 140:439-449.

Volenec, J.J. 1986. Nonstructural carbohydrate in stem base components of tall fescue during regrowth. Crop Sci. 26:122-127.

Wang, Z. and B. Huang. 2003. Genotypic variation in abscisic acid accumulation, water relations, and gas exchange for kentucky bluegrass exposed to drought stress. J. Amer. Soc. Hort. Sci. 128:349-355.

Warembourg, F.R. and H.D. Estelrich. 2001. Plant phenology and soil fertility effects on below-ground carbon allocation for an annual (Bromus madritensis) and a perennial (Bromus erectus) grass species. Soil Biol. Biochem. 33:1291-1303.

White, R.H., M.C. Engelke, S.J. Morton, and B.A. Ruemmele. 1992. Competitive turgor maintenance in tall fescue. Crop Sci. 32:251-256. 